\title{
Innovation potential of regional economy as a basis to build Russia's national innovation system
}

\author{
Igor V. Antonenko \\ Institute of Economics and Finance \\ Department of Economic Theory, World and Regional \\ Economy \\ Volgograd State University \\ Volgograd, Russia \\ antonenkoiv@ volsu.ru
}

\author{
Tatiana S. Sidorovich \\ Institute of Philology and Intercultural Communication \\ Translation Studies Department \\ Volgograd State University \\ Volgograd, Russia \\ sidorovich@volsu.ru
}

Inna V. Kudryashova

Institute of Economics and Finance

Department of Economic Theory, World and Regional Economy

Volgograd State University

Volgograd, Russia

kudryashovaiv@volsu.ru

\begin{abstract}
The paper focuses on innovation development of the Russian economy and formation of the national innovation system that ensures effective use of innovation potential and incentives for its growth. To build single innovation environment of the South Federal District aimed at effective innovation potential implementation within regional innovation systems it is recommended to strengthen integration of regions, public authorities, educational and research institutions, and industrial enterprises. Innovation potential implementation at the regional level has become a priority for state and local authorities which allows to set a path towards sustainable economic growth.
\end{abstract}

Key words - innovation climate in regions, regional innovation potential, innovation attrctiveness of regions, production potential, knowlrdge generation

\section{Introduction}

Nowadays, regional economy faces a number of institutional and organizational restrictions that make it difficult to implement regional innovation potential (IP); there are also gaps in technological and innovational development and in the process of innovation reproduction, all resulting in low chances to build a single innovation area of the region. Therefore, it is crucially important to consider conditions, opportunities, factor restrictions, forms, methods, and instruments to build and implement regional innovation potential

\section{Materials and Methods}

The works of Russian and foreign scholars in the field of innovative development theory, production factors, economic and innovative mechanism, regional aspects of innovative activity form the basis of the research.

Universal research methods, system, historical, statistical analyses, typological and classification modeling as well as structural and functional, subject-object, descriptive and comparative analyses provide the methodological basis for the study.

The author's studies and research, monographs and academic papers on the issues under analysis, as well as the data provided by the Federal State Statistics Service form an empirical basis of the research.

Laws and regulations of the President and the Government of the Russian Federation, the State Duma and constituent entities of the Russian Federation provide legal and regulatory framework of the research.

\section{Results}

\section{A. Specific character of regional economy's performance}

The efficiency of the national innovation system development is determined by the degree of concentration of innovation potential and capacities to implement it in the framework of the national innovation system (NIS). In this context, it is appropriate to consider the national innovation system as an organizational form for development and 
implementation of innovation potential; here, singling out constituent elements of the national innovation system and detailing their functions within the structural and functional approach would be required.

Table 1. Characteristics of constituent elements of the national innovation system as an organizational form of IP development and implementation

\begin{tabular}{|c|c|c|c|}
\hline $\begin{array}{c}\text { NIS } \\
\text { element }\end{array}$ & IP subject & $\begin{array}{c}\text { NIS } \\
\text { functions }\end{array}$ & $\begin{array}{c}\text { IP development } \\
\text { and } \\
\text { implementation }\end{array}$ \\
\hline $\begin{array}{l}\text { Managem } \\
\text { ent- } \\
\text { regulation }\end{array}$ & $\begin{array}{l}\text { Public sector: } \\
\text { 1. Bodies } \\
\text { responsible for } \\
\text { development } \\
\text { and } \\
\text { coordination of } \\
\text { innovative } \\
\text { policy; } \\
\text { 2) funding } \\
\text { organizations; } \\
\text { 3) regulatory } \\
\text { agencies }\end{array}$ & $\begin{array}{l}\text { 1. Innovative } \\
\text { policy- } \\
\text { making; } \\
\text { 2. Resource } \\
\text { mobilization } \\
\text { and } \\
\text { distribution; } \\
\text { 3. Creation } \\
\text { of regulatory } \\
\text { environment } \\
\text { and } \\
\text { incentives } \\
\text { for } \\
\text { innovation } \\
\text { development }\end{array}$ & $\begin{array}{l}\text { 1. Creation of } \\
\text { external } \\
\text { capabilities for IP } \\
\text { implementation } \\
\text { 2. Development } \\
\text { of incentives for } \\
\text { IP } \\
\text { implementation }\end{array}$ \\
\hline $\begin{array}{l}\text { Knowledg } \\
\mathrm{e} \\
\text { generation }\end{array}$ & $\begin{array}{l}\text { R\&D sector: } \\
\text { 1. The Russian } \\
\text { Academy of } \\
\text { Sciences and } \\
\text { sectoral } \\
\text { research } \\
\text { institutes; } \\
\text { 2. Universities } \\
\text { вyзы; } \\
\text { 3.laboratories }\end{array}$ & $\begin{array}{l}\text { 1. R\&D and } \\
\text { resource } \\
\text { distribution; } \\
\text { 2. Creation } \\
\text { of human } \\
\text { capital }\end{array}$ & $\begin{array}{l}\text { 3. Creation of } \\
\text { internal } \\
\text { capabilities for IP } \\
\text { implementation } \\
\text { by means of } \\
\text { R\&D aimed at } \\
\text { technological } \\
\text { innovations }\end{array}$ \\
\hline $\begin{array}{l}\text { Innovatio } \\
\mathrm{n} \\
\text { infrastruct } \\
\text { ure }\end{array}$ & $\begin{array}{l}\text { Technology } \\
\text { transfer sector: } \\
\text { 1. Information } \\
\text { Technology } \\
\text { Center; } \\
\text { 2. Technology } \\
\text { Transfer } \\
\text { center; } \\
\text { 3. Consulting } \\
\text { companies; } \\
\text { 4. Business } \\
\text { incubators }\end{array}$ & $\begin{array}{l}1 . \\
\text { Technology } \\
\text { diffusion; } \\
2 . \\
\text { Developmen } \\
\text { t of new } \\
\text { sectors }\end{array}$ & $\begin{array}{l}\text { 4. IP resource } \\
\text { element } \\
\text { implementation }\end{array}$ \\
\hline $\begin{array}{l}\text { Business } \\
\text { sector }\end{array}$ & $\begin{array}{l}\text { Innovation } \\
\text { commercializat } \\
\text { ion sector: } \\
\text { 1. Industrial } \\
\text { enterprises; } \\
\text { 2. Innovative } \\
\text { enterprises }\end{array}$ & $\begin{array}{l}\text { Use of } \\
\text { innovations }\end{array}$ & $\begin{array}{l}\text { 5. Result of IP } \\
\text { implementation }\end{array}$ \\
\hline
\end{tabular}

Constituent elements of the national innovation system are: management and regulation; science and education as a source of innovation ideas; business sector which implements innovations; innovative infrastructure which contributes to commercialization of knowledge. It should be noted that the functions of the subjects in the framework of some elements of the national innovation system and IP subjects are in many respects comparable, and factors that unite their functions are gaining, dissemination and use of knowledge [1].

Each element of the national innovation system according to its function corresponds to a specific set of IP subjects (see Table 1).

The regional innovation system (RIS) can be distinguished as a subsystem of the national innovation system due to traditional territorial division of labour; the key condition for the regional innovation system to arise is spatial concentration of innovations in the form of innovative enterprises clusters, development of new elements within the system, and increasing complexity of the subsystem resulting in its growth and development.

Thus, the regional innovation system reflects territorial development of production conditions and factors contributing to both internal and external capacities for innovation potential implementation.

\section{B. Management system for the regional innovation potential implementation}

Below are listed the subsystems of the regional innovation system distinguished in accordance with the levels and subjects of innovative activity. The system consists of the elements united in blocks viewed as subsystems with hierarchical relationships [3].

From the above, it can be ascertained that the regional innovation system consists of the following subsystems:

- institutional, organizational, financial and investment subsystems to ensure external capabilities and incentives for innovation potential implementation;

- research and development, and education subsystems to insure internal capabilities for innovation potential implementation;

- infrastructure and information subsystem to insure the implementation of resource element of innovation potential;

- production-technology, cluster-sector subsystems, and resource subsystem to insure the result of innovation potential implementation. 


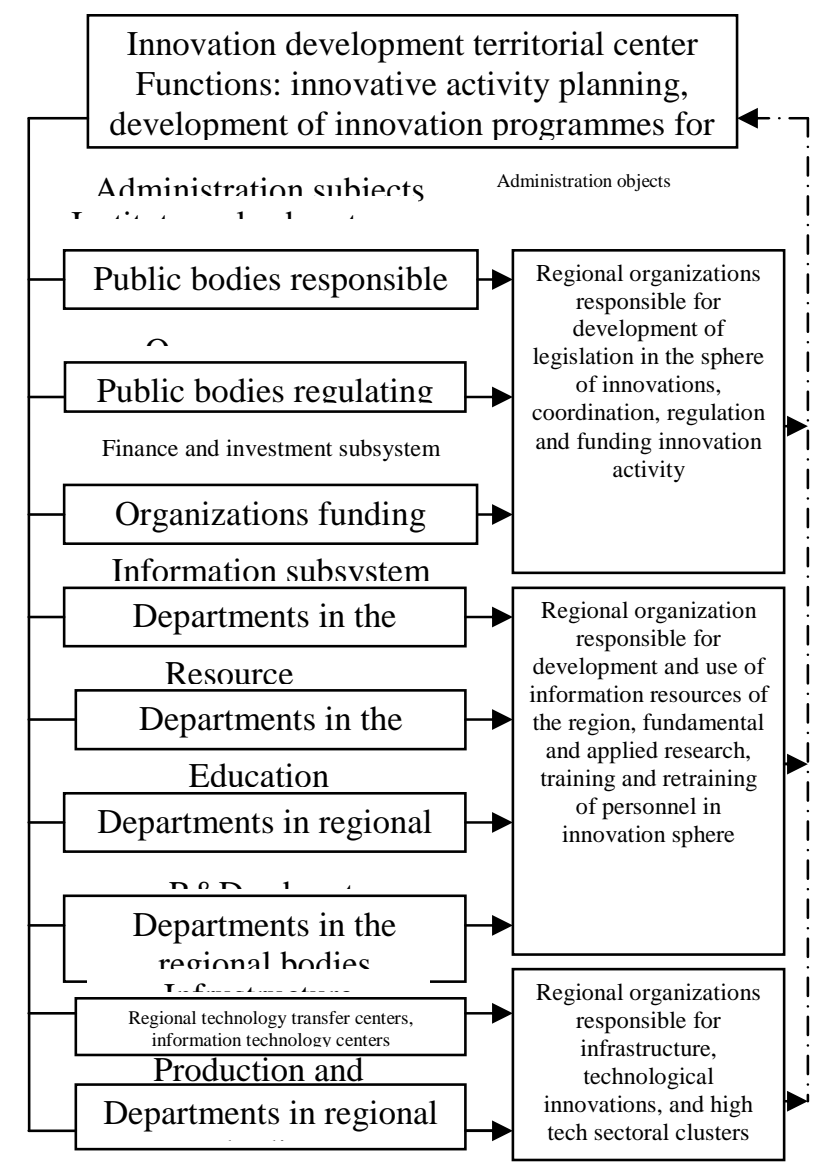

Fig. 1 Institutional and organizational structure of regional innovation potential management (compiled by the author)

It is relevant to describe the structure of regional innovation potential management needed for consolidation of common interests and cooperation of efforts of the subsystems of the regional innovation system (see Picture 1).

Effective management of the regional innovation system requires a regional center to coordinate innovative activity which is viewed as an element of organizational subsystem.

To identify the capacities of RIS levels and elements the regional innovation system can be presented as a multilevel structure with three macro blocks:

Knowledge generation macro block presents internal capacities for innovation potential implementation; Innovation infrastructure macro block ensures implementation of resource element of innovation potential; Business sector macro block represents the result of innovation potential implementation [2].

Each macro block consists of a number of components. In particular, business sector macro block is responsible for innovative character of enterprises of the South Federal
District (SFD) and conditions needed for innovative business. Knowledge generation macro block presents the level of development of fundamental and applied research by means of analysis of their types. Innovation infrastructure macro block presents processes of knowledge diffusion and transfer at the regional level.

Business sector macro block in the RIS structure ensures the result of IP implementation in the South Federal District which is characterized by low innovation activity and innovative enterprises that do not seek to win competitive foreign markets with small share of innovative products in total volume of shipped products.

Knowledge generation macro block forms internal capacities for IP implementation at the regional level; these capacities are characterized by limited knowledge intensity of the SFD regions, where types of research do not meet the proportions of production development with decreasing share of applied research and technological innovation spending, as a percentage of the total amount of shipped products.

Innovation infrastructure macro block ensures implementation of IP resource element and is mainly focused on knowledge diffusion in the domestic market where technological sharing shows unstable dynamics and do not have an adequate place in innovative activity structure; the scope of research and innovative activity is decreasing, and thus R\&D effectiveness is reduced and limited by the domestic market; and intellectual property market in the South Federal District is highly underdeveloped.

C. Strategies for IP implementation in the regions of the South Federal District

The comparative analysis of IP implementation strategies has been conducted on the basis of calculation of the region's technological sharing index (RTSI), sectoral knowledge intensity index (SKII), and technological independence coefficient (TIC). To implement effectively IP in the regions of the South Federal District it could be recommended to use a combined strategy for sectoral growth with the focus on knowledge intensive sectors. Thus, if RTSI $\geq 1$ the region is a donor of technologies; if RTSI $\geq 0.5$ the region is a recipient which uses the imitation strategy of technological innovations; if $0,5 \leq \mathrm{RTSI}<1$ the region can use a combined strategy, i.e. imitation-adaptation strategy and invention strategy which characterize the degree of technological dependence/independence of the region.

For instance, in 2014 the Rostov region was a donor of technologies (RTSI - 3.31) while in 2015-2016 the region demonstrated imitation type of innovative development (the Volgograd region: RTSI 0.15-0.05; the Rostov region: RTSI $0.30-0.31$; the Krasnodar region: RTSI 0.59-0.21) [4]. Therefore, negative dynamics of international technological sharing index of the Volgograd and Rostov regions, and weak positive trend of the Krasnodar region show high technological dependence on developed countries. 
Thus, it would be desirable for the Krasnodar region with $0.5 \leq$ RTSI $<1$ to use invention strategy to produce electrical equipment, electronic and optical devices. An essential feature of these sectors is sectoral specialization with invention strategy of sectoral growth. Also, the Krasnodar region is recommended to use imitation-adaptation strategy in machinery production (SKII - 0.03), transport vehicles and equipment production (SKII - 0.17), foodstuff production (SKII - 0.009) as R\&D in these sectors is insufficient for active innovative growth. Adaptation of attracted technologies to Russian conditions will allow to intensify sectoral development in the regions.

Invention strategy will be also effective in the Rostov region to produce electrical equipment, electronic and optical devices; medical devices, measuring instruments, photo- and cinema equipment. The Rostov region is also recommended to use imitation-adaptation strategy in IT sphere, in production of vessels, aircraft and spacecraft production, pharmaceutical manufacturing, machinery, transport vehicles and equipment production.

The Volgograd region can improve competitiveness of its industry by means of imitation-adaptation strategy in traditional sectors such as metallurgy, chemical production and foodstuff production.

Therefore, index ratio analysis has shown that invention strategy of technologically independent type (SKII $\geq 2$; RTSI $\geq 1$ ) cannot be used now due to low knowledge intensive economy, low rates of technological independence coefficient and international technological sharing index in the regions of the South Federal District.

\section{Conclusion}

In accordance with the world practices the NIS institutional basis is made up of two types of subsystems: science and technology clusters and regional innovation systems.

The regional innovation system has been structuralized in accordance with the levels and subjects of innovative activity. The system's structure consists of elements united in the blocks viewed as subsystems with hierarchical relationships.

The RIS structure consists of a number of subsystems: institutional subsystem, organizational subsystem, finance and investment subsystem which are considered as the levels of the regional innovation system and contribute to external capabilities and incentives for IP implementation; R\&D and education subsystem which create internal capabilities for IP implementation; infrastructure and information subsystem ensures the implementation of IP resource element; production-technology, cluster-sector and resource subsystems ensure the result of IP implementation.

The IP development dynamics of the macro region has revealed the following trends in the innovative development of the regions of the South Federal District.

First, the Rostov and Volgograd regions show stable IP development, and take leading positions in terms of IP development among the SFD regions in 2010-2016. So, for this period the rates of IP integral indices have reduced insignificantly and stabilized.

Second, the Krasnodar and Astrakhan regions show satisfactory IP performance with a slight decrease in IP integral indices.

\section{References}

[1] Innovative Russia - 2020. Strategy 2020: New outlines of Russian innovation policy. The Ministry for Economic Development and Trade. - Moscow, 2010. pp. 17-18.

[2] Antonenko I.V. Innovation development sectoral trajectories of the South Russian regions // Regional and Sectoral Economic Studies. Spain. Vol. 14-2 (2014), pp. 31-38.

[3] Antonenko I.V., Lisovskaya N.V. The innovation climate rating of the regions of the South Federal District // Regional Economics: Theory and Practice Journal. Vol. 2 (377), 2015, pp. 48-55.

[4] Central statistics database [Electronic resource] Key performance indicators of some sectors / Science and innovation / Data on innovative activity of organizations / Share of enterprises that implement technological innovations // Access mode: http://www.gks.ru/dbscripts/Cbsd/DBInet.cgi 